\title{
Government trade restrictions and international price volatility
}

\author{
Kym Anderson \\ University of Adelaide, Australian National University, and CEPR \\ kym.anderson@adelaide.edu.au
}

May 2012

The author is grateful for discussions with Will Martin and Signe Nelgen and for financial support from the Australian Research Council, the World Bank, and Australia's Rural Industries Research and Development Corporation. Views expressed are the author's alone. Forthcoming in a special issue of the Elsevier journal, Global Food Security 1(2): 157-66, December 2012. 


\begin{abstract}
National governments dislike food price volatility to varying extents. When some of them use trade measures to insulate their domestic market from international food price fluctuations, that volatility is amplified. This in turn prompts more countries to follow suit. However, when both food-exporting and food-importing countries so respond, each group becomes less capable of preventing domestic price volatility. This paper examines empirically the extent of insulation in both groups of countries, and also in high-income versus developing countries. It also provides an estimate of the contribution of such government actions to international food price spikes. A multilateral agreement to limit such government responses would reduce the need for all countries to so intervene, and allow more-efficient generic social protection policies to deal with the most vulnerable cases.
\end{abstract}

Keywords: Food price stabilization; Domestic market insulation; Trade-distorting measures

JEL codes: F14, Q17, Q18

\title{
Highlights:
}

- Fluctuations in trade barriers contribute to international price instability;

- Both food-exporting and food-importing countries vary their trade barriers;

- Such reactions by each country group undermines the other's attempt to stabilize;

- A multilateral agreement to persist is needed to limit these offsetting actions.

\section{Author contact:}

Kym Anderson

School of Economics

University of Adelaide

Adelaide SA 5005 Australia

Phone +6188303 4712

Fax +61 882231460

kym.anderson@adelaide.edu.au 


\section{Government trade restrictions and international price volatility}

\section{Introduction}

The recent upward spike in international food prices caused panic in numerous developing countries. It may have even contributed to the latest political revolutions in several Arab countries. Commodity price volatility is also undesirable because it reduces consumer and investor confidence in all countries, thereby potentially lowering global economic growth. It also causes swings in the economic welfare of net sellers of food versus net buying households, and hence also between net food-exporting and food-importing countries.

Understanding the causes of international food price volatility is thus an important first step towards reducing this global problem. Much has been written and spoken about possible causes of the most-recent fluctuations in those prices, including in the mass media and in international fora such as the G20 (FAO et al. 2011). Weather is obviously one possible supply-side contender, and climate change may be adding to the frequency and severity of extreme weather events. However, since growing seasons vary across the globe, international trade and consumer substitutability normally can even out their effects on the international price of various foods. Speculators are sometimes blamed, although in fact their contribution is usually the opposite because they tend to buy when prices are high and sell when they are low. A problem can arise though if global stocks are depleted while prices are still rising - which Wright (2011) argues was one of the contributors to the 2008 food price spike.

The purpose of this paper is to highlight another contributor to the volatility of international food markets, namely national governments' agricultural trade policies. Those policies contribute in two ways: through 'thinning' the international market for food in normal years; and through 'insulating' domestic markets from, and thereby adding to, international price swings in abnormal years. Over the past half century the former has been a consequence of rich industrial countries protecting farmers relative to manufacturers and poor agrarian countries doing the opposite (for reasons explained in Anderson 1995 and 2010). 
The latter is the result of fluctuations in food trade restrictions, stemming from the fact that national governments dislike food price volatility. When some governments alter the restrictiveness of their food trade measures to insulate their domestic markets from international price fluctuations, the volatility faced by other countries is amplified. That reaction therefore prompts more countries to follow suit, which not only further amplifies but also lengthens the duration of each price spike. The irony is, however, that when both foodexporting and food-importing countries so respond, each country group undermines the other's attempts to stabilize its domestic markets. That is, what seems like a solution to each country's concern if it were acting alone turns out to be less effective, the more other countries respond in a similar way.

This paper first explains the basic national and global economics behind both types of trade policy contributions to the volatility of international food prices. It then reviews empirical evidence on trends and fluctuations in the extent of those policy interventions, and the evolution through time of their market, welfare, inequality and poverty effects. It highlights the substantial role that trade restrictions continue to play in 'thinning' international food markets, and the roles that fluctuations in those trade restrictions have played in amplifying substantially international price volatility and yet reducing very little domestic food price volatility. The final section examines national and multilateral policy options for reducing the contribution of trade policies to global food price volatility, and for improving the effectiveness of social protection policies to deal with the most vulnerable households whose food security would otherwise be adversely affected by food price spikes.

\section{Global Economic Effects of National Trade Policies}

Consider first the 'thinning' argument. If rich industrial countries protect their farmers from import competition more than they assist their manufacturers and producers of other tradables, that policy choice encourages domestic food production and discourages domestic food consumption in those countries. It thus reduces demand and so lowers the relative price of food and reduces the volume traded in the international food marketplace. If poor agrarian countries do the opposite, for example through taxing farm exports or protecting manufacturers from import competition, that discourages domestic food production and encourages domestic food consumption in those developing countries. That in turn reduces supply and so further lowers the relative price of food and reduces the volume traded in the 
international food marketplace. These two country groups' trade policies thus reinforce each other's impacts on that international market. (They also reinforce each other in discriminating against net sellers of farm products in developing countries - including in those countries whose governments choose not to adopt anti-agricultural trade policies.) The important point in terms of price volatility is that such a policy regime, through reducing the volume of food trade across national borders, 'thins' the international food market and thus makes its price more volatile in the face of any given-sized global supply or demand shock. This same impact on the price and volume of global trade applies if the two country groups are simply food importers and food exporters, rather than distinguished by per capita income.

Turning to the 'insulating' aspect of farm trade policies, it is again helpful to consider the same two country groups, food importers and food exporters. Suppose a severe weather shock at a time of low global stocks causes the international food price to suddenly rise. Those national governments wishing to avert losses for domestic food consumers may alter their food trade restriction so that only a fraction of that price rise is transmitted to their domestic market. For example, imposing or raising an export tax or an equivalent quantitative restriction on food exports would mean the domestic price in a food-surplus country would rise less than the border price. Similarly, lowering any import tax on food would mean the domestic price in a food-deficit country would rise less than the border price. Hence it is not surprising that governments, in seeking to protect domestic consumers from an upward spike in international food prices, consider a change in trade measures as an appropriate response. That response raises the consumer subsidy equivalent/lowers the consumer tax equivalent of any such trade measure, and does the opposite to producer incentives. Conversely, a global shock that expanded supply on the international food market and caused its price to slump may trigger the opposite reaction by governments concerned for the welfare of their farmers. That is, food export taxes may be lowered in food-surplus countries and tariffs may be raised in food-importing countries, again to ensure only a fraction of the change in the international price is transmitted to those countries' domestic markets. In that scenario the response by governments lowers the producer tax equivalent/raises the producer subsidy equivalent of any such trade measure, and does the opposite to consumer incentives.

However, if such domestic market insulation using trade measures is practiced by large countries, or by a sufficiently large number of small countries, it turns out to be not very effective in keeping domestic price volatility below what it would be in the international marketplace if no government so responded. To see why this can lead to ineffective outcomes, it is helpful to refer to Figure 1, which depicts the international market of food. In 
a normal year, the excess supply curve for the world's food-exporting countries is $\mathrm{ES}_{\mathrm{o}}$ and the excess demand curve for the world's food-importing countries is $\mathrm{ED}_{\mathrm{o}}$. In the absence of any trade costs such as for transport, equilibrium in a normal year would be at $\mathrm{E}_{\mathrm{o}}$ with $\mathrm{Q}_{\mathrm{o}}$ units traded at international price $\mathrm{P}_{\mathrm{o}}$.

\{Figure 1 about here

An adverse season in some exporting countries at a time when global stocks are low would shift the excess supply curve leftwards to $\mathrm{ES}_{1}$. If there were no policy responses, the equilibrium would shift from $\mathrm{E}_{\mathrm{o}}$ to $\mathrm{E}_{1}$; and the international price and quantity traded across national borders would change from $\mathrm{P}_{\mathrm{o}}$ and $\mathrm{Q}_{\mathrm{o}}$ to $\mathrm{P}_{1}$ and $\mathrm{Q}_{1}$. However, if the higher price prompts governments to alter their trade restrictiveness, there will be additional effects. On the one hand, suppose some of the food-exporting countries choose to impose or raise an export tax. That would move the excess supply curve further to the left, say to $\mathrm{ES}_{2}$. This would move the equilibrium to $E_{2}$ and raise the international price further, to $P_{2}$, but the domestic price in those export-restricting countries would be $\mathrm{P}_{\mathrm{x}}$ which is below $\mathrm{P}_{1}$. Such a reaction thus provides partial insulation in those exporting countries from the initial exogenous shock to the international market. Furthermore, their combined actions reduce aggregate exports to $\mathrm{Q}_{2}$ and cause the international terms of trade to turn further in their favor, because of the additional reduction in available supplies on the international market. That means, however, that food-importing countries face an even higher international price, at $\mathrm{P}_{2}$ instead of $\mathrm{P}_{1}$.

On the other hand, suppose some protective food-importing countries were to reduce their barriers to food imports in response to the international price rising from $\mathrm{P}_{0}$ to $\mathrm{P}_{1}$. That would shift the excess demand curve to the right, say to ED'. In that case the new equilibrium would be at E', involving Q' units traded at international price P'. That response would provide partial insulation in those food-importing countries from the initial exogenous shock to the international market: their domestic price would rise by only $\mathrm{MN}$ instead of by $\mathrm{ME}^{\text {' in }}$ Figure 1. However, the combined actions of those importing countries cause the international terms of trade to turn further against them.

What if both country groups intervene, each seeking to at least offset the effect on their domestic price of the other country group's policy response? In practice, the more one group seeks to insulate its domestic market, the more the other group is likely to respond. The example of such actions shown in Figure 1 involves the curves shifting simultaneously to $\mathrm{ES}_{2}$ and ED', in which case the international price is pushed even higher to $\mathrm{P}_{3}$ while the domestic price in each country group would be lower by $\mathrm{E}_{3} \mathrm{E}_{1}$. That is, in that particular case the 
domestic price (and the quantity traded internationally, $\mathrm{Q}_{1}$ ) would be exactly the same as if neither country group's governments had altered their trade restrictions. The terms of trade would now be even better for the food-exporting country group, and even worse for foodimporting countries. Aggregate global welfare would be the same as when neither country group so intervenes, but there would be an economic welfare transfer from food-importing to food-exporting countries, via the terms of trade change, equal to areas $\mathrm{P}_{1} \mathrm{E}_{1} \mathrm{E}_{3} \mathrm{P}_{3}$.

Conversely, if the exogenous weather shock was of the opposite sort (a bumper harvest) which depressed the international price even after purchases by stockholders, and if governments sought in that case to protect their farmers from the full force of the price fall, the international price fall would be accentuated to the benefit of food-importing countries.

Clearly, both such attempts at price insulation exacerbate international price volatility while doing little or possibly nothing to assist those most harmed by the initial exogenous weather shock.

More than that, this use of trade measures can be inefficient and possibly inequitable, and it may even add to global poverty despite its motivation being to reduce the risk of a rise in national poverty. To see that in the case of an upward spike in the international price, note that an import tax is the equivalent of a consumer tax and a producer subsidy, hence lowering it also reduces the extent to which the measure assists producers of the product in question. Likewise, an export tax is the equivalent of a consumer subsidy and a producer tax, so raising it not only helps consumers but also harms farmers. If farming is discouraged, the demand for labor on farms falls, and with it the wages of unskilled workers not only in farm jobs but also in non-farm jobs - and more so the more agrarian is the economy. Thus while poor households may benefit on the expenditure side from a measure that reduces the extent to which the cost of food consumption would otherwise rise, they could be harmed on the earnings side if they are sellers of food or suppliers of unskilled labor. Such trade policy responses therefore could add to rather than reduce poverty (Ivanic and Martin 2008; Aksoy and Hoekman 2010). That could in turn add to food insecurity, since food security refers to not only national availability but also economic access to and effective utilization of food (Pinstrup-Andersen 2009; Barrett 2010).

In the case of a small food-exporting country unable to influence its terms of trade, an increase in export restrictions is likely to reduce its national economic welfare, because such measures distort domestic production in addition to lowering the consumer price of food. Trade measures are wasteful too if it is only the poorest consumers who need to be helped, since a trade measure affects all food consumers in the country and in proportion to their 
expenditure on food. In the case of opposite changes to trade measures, aimed at protecting farmers from a slump in international food prices, it is net buyers of food who are inadvertently harmed by such trade policy responses, and all food sellers rather than just the poorest are helped - and in proportion to their marketed output, thereby adding to farm income inequality.

\section{Empirical Evidence}

There is now a considerable body of evidence to suggest that national food trade policies are having a non-trivial impact in increasing the volatility of international food markets and, through that mechanism, adversely affecting global food security. This section provides a brief review of pertinent studies that collectively lead one to that conclusion. It begins with evidence showing that the global pattern of trade policies since the 1950s has 'thinned' international food markets and, even ignoring the impact of that on volatility, has contributed to global poverty and thereby global food insecurity. It then turns to evidence showing the extent to which countries' trade policies 'insulate' their domestic food markets, the impact of that on international food prices, and hence the effectiveness of those national policies in preventing a rise in domestic food prices when international prices spike.

\subsection{How much have trade policies 'thinned' the international food market?}

Most countries have some forms of taxes or quantitative restrictions on imports of some products, and many developing countries have also taxed or quantitative restricted some of their exports. Less commonly, countries occasionally will subsidize exports or imports too. In addition, it was not uncommon before the 1990s for developing countries to operate multiple exchange rate regimes, which also had a strong anti-trade bias. And any domestic producer or consumer price subsidies or taxes on tradable products also alter volumes of trade.

For decades agricultural subsidies and protection from imports in high-income (and some middle-income) countries have been depressing international prices of farm products. The Haberler (1958) report to GATT Contracting Parties forewarned that such distortions might worsen, and indeed they did between the 1950s and the early 1980s in East Asia, North America and Western Europe (Anderson, Hayami and Others 1986). Meanwhile, the governments of many developing countries have directly taxed their farmers over the past 
half-century. A well-known example is the taxing of exports of plantation crops in postcolonial Africa (Bates 2005). At the same time, many developing countries chose also to overvalue their currency, and to pursue an import-substituting industrialization strategy by restricting imports of manufactures. Together those latter measures indirectly taxed producers of other tradable products in developing economies, by far the most numerous of them being farmers (Krueger, Schiff and Valdés 1988, 1991). Thus the price incentives facing farmers in many developing countries have been depressed by both own-country and other countries' agricultural price and international trade policies.

This disarray in world agriculture, as Johnson (1973) described it in the title of his seminal book, means there has been over-production of farm products in high-income countries and under-production in low-income countries. It also means there has been less international trade in farm products than would be the case under free trade, thereby thinning markets for these weather-dependent products and thus making them more volatile. Using a model of world food markets as of 1990, Tyers and Anderson (1992, Table 6.9) found that high-income country pro-farm policies lowered international food prices by 20 percent, but that most of that was offset by developing countries' anti-agricultural policies. They also found that high-income country policies lowered the volume of international food trade by 25 percent. However, developing countries' policies did likewise, and the combined effect was to shrink global food trade in 1990 by 56 percent - making it very much more susceptible to exogenous global supply or demand shocks.

During the past 25 years, however, numerous countries have begun to reform their agricultural price and trade policies: since the latter 1980s high-income countries have steadily lowered their assistance to farmers and have decoupled some of that support from production, while developing countries have gradually lowered their farm export taxes and their import tariffs on manufactures. One effect is a convergence towards zero in the estimated nominal rate of assistance (NRA) to farmers, which is the percentage by which gross earnings from farming in each country exceed (or, if negative, fall short of) what they would in the absence of national agricultural price and trade policies (see Figure 2).

Despite the comprehensiveness of those trade reforms, they have raised only very slightly the global extent to which farm products are traded internationally: the share of primary agricultural production exported globally, including intra-European Union trade, rose from 13 percent to just 16 percent in the two decades to 2000-04 (Sandri, Valenzuela and Anderson 2007). One reason for this small aggregate global response is that high-income countries lowered not only their import restrictions but also their export subsidies. A second 
reason is that while developing countries phased out their farm export taxes, they also raised their tariffs on farm imports. As a result, international food markets are not much 'thicker' now than they were a quarter-century ago.

According to global economy-wide modelling results reported in Valenzuela et al. (2009), however, liberalization of remaining trade barriers as of 2004 would raise the share of farm production exported globally by another four percentage points. Thus plenty of scope still remains to 'thicken' international food markets and thereby make them less volatile. Such liberalization also would lower global poverty, according to more-detailed modelling that draws on those global economy-wide model results (Anderson et al. 2010, 2011). Global food security would thus be boosted by both of those effects of further trade liberalization even before taking into account the 'insulating' feature of current food trade policies, to which we now turn.

\{Figure 2 about here $\}$

\subsection{How much have trade policies 'insulated' domestic food markets from international price volatility?}

The above empirical evidence focuses on trends in trade-distorting policies. Another feature of those food market interventions is that they are negatively correlated with international food price movements. NRAs fluctuate considerably around trend, and not only in extreme price spike periods. Figure 3 shows the extent of that negative correlation for the three key grains, even after averaging across as many as 82 countries.

\{Figure 3 about here

It is possible to estimate the proportion of any international price fluctuation that is transmitted to domestic markets within twelve months. It is also possible to obtain a crude back-of-the-envelope estimate how much trade policy responses exacerbate international price spikes. Anderson and Nelgen (2012a) have estimated a short-run elasticity of transmission of the international product price to the domestic market for the three key grains. Following Nerlove (1972) and Tyers and Anderson (1992, pp. 65-75), they use a partial-adjustment geometric distributed lag formulation to estimate elasticities for each product for all focus countries for the period 1985 to 2010. Specifically, they assume that associated with the border price $p_{t}{ }^{*}$ there is a 'target' domestic price $\overline{p_{t}}$, towards which policy ensures that the actual domestic price, $p_{t}$, moves only sluggishly. Changes in this target price 
might respond incompletely, even in the long run, to corresponding changes in the border price. If all prices are expressed in logarithms, the target domestic price then has the following relationship with the border price:

$$
\overline{p_{t}}=p_{0}+\phi_{L R}\left(p_{t}^{*}-p_{0}^{*}\right)
$$

where $\phi_{L R}$ is the long-run price transmission elasticity and the values of $p_{0}$ and $p_{0}^{*}$ are the domestic and border prices in the base period. In the short-run, the actual domestic price adjusts only partially each year to any change in the target domestic price:

$$
p_{t}-p_{t-1}=\delta\left(\overline{p_{t}}-p_{t-1}\right)
$$

where the parameter $\delta$ gives the fraction of the ultimate adjustment that takes place in one year. By substituting (1) into (2) to eliminate the unobservable target price, the following reduced form, which is suitable for fitting to data, is obtained:

$$
p_{t}=\delta\left(p_{0}-\phi_{L R} p_{0}^{*}\right)+(1-\delta) p_{t-1}+\delta \phi_{L R} p_{t}^{*}=\mathrm{a}+\mathrm{b} p_{t-1}+\mathrm{c} p_{t}^{*}
$$

where, again, if the current US dollar prices are expressed in logarithms, the short-run (oneyear) elasticity of price transmission, call it $\phi_{S R}$, is simply $\delta$ times the long-run elasticity. Thus the estimate of the short-run elasticity is the regression coefficient $\mathrm{c}$ and the long-run elasticity estimate is $c /(1-b)$.

Table 1 summarizes the estimates. The average of estimates for the short-run transmission elasticity over the 25 years to 2010 ranges from 0.73 for soybean down to just 0.43 for sugar. The unweighted average across these ten key farm products is 0.56 , suggesting that within one year, barely half the movement in international prices of farm products is transmitted domestically on average. These estimates are consistent with a recent study by Minot (2011) of 11 Sub-Saharan African countries. Despite using a somewhat different methodology, he estimated short-run price transmission elasticities for key staple foods that averaged 0.63. Earlier multicountry studies by Comforti (2004) and Tyers and Anderson (1992, Appendix 2) generally got short-run estimates below 0.5.

\{Table 1 about here $\}$

Using their stochastic model of world food markets and their estimated price transmission elasticities (based on price data from the previous 25 years), Tyers and Anderson (1992, pp. 227-8) ran 200 repeated simulations with random weather shocks. They found that the coefficient of variation of international food prices would fall from 34 to 10 percent if all countries agreed in 1990 to cease their domestic price-insulating practices and instead maintain constant ad valorem trade tax rates. In most of the 16 developing economies they considered, the coefficient of variation for domestic prices (the standard deviation 
divided by the mean) would fall substantially if all countries refrained from using the type of price insulating prices they had used in the past quarter-century. In a number of these cases, such as Bangladesh, Thailand and South Africa, the reductions in domestic price instability were estimated to be dramatic, with the coefficient of variation in Bangladesh, for instance, falling from 26 to 8 percent. In the few cases where the coefficient of variation of domestic prices was estimated to rise, the increases were much smaller. Given that the extent to which variations in trade barriers are used to insulate domestic food markets from international food price volatility appears to have been no less in the past 25 years than in the generation prior to 1990 , the coefficient of variation of international food prices could well fall by one-third if all countries agreed today to cease their domestic price-insulating practices. And recall that this is additional to the contribution that trade liberalization could make to reducing international food price volatility through 'thickening' international food markets (discussed above in the section 3.1).

\subsection{How much do trade policy responses exacerbate international price spikes?}

With the help of some simplifying assumptions, it is possible to estimate without a complex stochastic simulation model the extent to which government trade policy reactions contribute to an international price spike such as in 2008 or in 1974 for individual commodities. Martin and Anderson (2012) point out that this can be done by assuming a homogenous product whose global market equilibrium condition, assuming perfect competition and zero trade costs, is:

(4) $\Sigma_{\mathrm{i}}\left(\mathrm{S}_{\mathrm{i}}\left(\mathrm{p}_{\mathrm{i}}\right)+\mathrm{v}_{\mathrm{i}}\right)-\Sigma_{\mathrm{i}} \mathrm{D}_{\mathrm{i}}\left(\mathrm{p}_{\mathrm{i}}\right)=0$

where $S_{i}$ is the supply in country $i ; p_{i}$ is the country's domestic price; $v_{i}$ is a random weatherrelated exogenous production shift variable for that country; and $D_{i}$ is demand in country $i$ (assumed to be not subject to shocks from year to year). Assume further that border measures are the only price-distorting policy intervention to be used, in which case we can define a single variable for the power of the trade tax equivalent, $T_{i}=\left(1+t_{i}\right)$ where $t_{i}$ is country $i$ 's rate of tax on trade.

Totally differentiating equation (4), rearranging it, and expressing the results in percentage change form yields the following expression for the impact of a set of changes in trade distortions on the international price $\mathrm{p}^{*}$, assuming the policy changes are independent of the exogenous supply shocks: 
(5) $\hat{\mathrm{p}}^{*}=\frac{\sum_{\mathrm{i}} \mathrm{H}_{\mathrm{i}} \widehat{\mathrm{v}}_{\mathrm{i}}+\sum_{\mathrm{i}}\left(\mathrm{H}_{\mathrm{i}} \gamma_{\mathrm{i}}-\mathrm{G}_{\mathrm{i}} \eta_{\mathrm{i}}\right) \widehat{\mathrm{T}}_{\mathrm{i}}}{\sum_{\mathrm{i}}\left(\mathrm{G}_{\mathrm{i}} \eta_{\mathrm{i}}-\mathrm{H}_{\mathrm{i}} \gamma_{\mathrm{i}}\right)}$

where $\widehat{\mathrm{p}}^{*}$ is the proportional change in the international price; $\widehat{v_{l}}$ is an exogenous stochastic shock to output such as might result from above or below average weather; $\eta_{i}$ is the price elasticity of demand; $\gamma_{i}$ is the price elasticity of supply; $G_{i}$ is the share, at the international price, of country $\mathrm{i}$ in global demand; and $\mathrm{H}_{\mathrm{i}}$ is the share of country $\mathrm{i}$ in global production. That is, the impact on the international price of a change in trade distortions by country $i$ depends on the importance of that country in global demand and supply $\left(\mathrm{G}_{\mathrm{i}}\right.$ and $\left.\mathrm{H}_{\mathrm{i}}\right)$, as well as the responsiveness of its production and consumption to price changes in the country (as represented by $\gamma_{\mathrm{i}}$ and $\left.\eta_{\mathrm{i}}\right)$.

If it is assumed that output cannot respond in the short run, and that inventory levels are low enough that stock adjustments have limited effect (as is typically the case in a price spike period - see Wright 2011), then $\gamma_{i}=0$. If one further assumes that the national elasticities of final demand for the product $\left(\eta_{i}\right)$ are the same across countries, then equation (5) reduces to:

(6) $-\sum_{i} G_{i} \widehat{T}_{i}=\widehat{T}$

which is just the negative of the consumption-weighted global average of the $\hat{T}_{i}{ }^{\prime} s$, call it $\widehat{T}$.

However, if the changes in trade restrictiveness are not independent of the exogenous supply (or any other) shocks, then

(7) $\hat{\mathrm{p}}^{*}=\widehat{T}+R+(\widehat{T} * R)$,

from which it follows that $\mathrm{R}=\left(\hat{\mathrm{p}}^{*}-\widehat{T}\right) /(1+\widehat{T})$, where $\mathrm{R}$ refers to the rest of the influences on $\mathrm{p}^{*}$. In that case, and if the interaction term is distributed proportionately, the contribution of the changes in trade restrictiveness to the international price change, in proportional terms, is $\frac{\widehat{T}}{\widehat{T}+R}$.

Estimates of those indicators are summarized for the key grains in Table 2. For rice, $-\widehat{T}$ (the cumulative proportional decline in the Nominal Assistance Coefficient, where NAC $=1+\mathrm{NRA} / 100)$ is shown in the first row of Table 2 to be 0.37 between 2006 and 2008. The comparable numbers for wheat and maize are 0.12 and 0.08 , respectively. According to World Bank (2012) data, the international price of rice increased by 113 percent between 2006 and 2008, and the prices of wheat and maize by 70 and 83 percent, respectively (middle rows of Table 2). Thus these estimates suggest that altered trade restrictions during the 200608 period caused international prices to be higher by 0.40 for rice, 0.19 for wheat, and 0.10 for maize (bottom third of Table 2). The unweighted average of these three, at 0.23 , is the 
same as for 1972-74 (first column of Table 2), although the price spikes were somewhat larger then.

\{Table 2 about here

It is possible to apportion those policy contributions between country groups. Table 3 reports the contributions of high-income versus developing countries, and also of exporting versus importing countries. During 2006-08, developing countries were responsible for the majority of the policy contribution to all three grains' price spikes, whereas in 1972-74 the opposite was the case except for rice. As for exporters versus importers, it appears exporters' policies had the majority of the influence, other than for wheat in the 1970s, but importers made a very sizeable contribution as well.

\{Table 3 about here

In the light of these estimates, how effective were changes in trade restrictions in limiting the rise in domestic prices? The proportional rise in the international price net of the contribution of changed trade restrictions is $\mathrm{R} /(\widehat{T}+\mathrm{R})$. That fraction, when multiplied by the international price rise shown in the middle part of Table 2, is reported in the second column of Table 4, where it is compared with the proportional rises in the domestic price in our sample of countries. The numbers for 2006-08 suggest that, on average for all countries in the sample, domestic prices rose slightly more than the adjusted international price change for wheat, and only slightly less for maize and just one-sixth less for rice. The extent of insulation was greater in developing countries, especially for wheat and maize, which is consistent with the finding from the middle columns of Table 3 that their policymakers contributed more to the price spike than governments of high-income countries. This recent experience contrasts with the early 1970s, when high-income countries were much more insulated than recently. These results suggests that the combined responses by governments of all countries have been sufficiently offsetting as to do very little to insulate domestic markets from this recent international food price spike.

\{Table 4 about here $\}$

\section{Policy Implications}

The above estimates support the a priori reasoning in Section 2 that national trade restrictions add non-trivially to international food price volatility in at least two ways: through 'thinning' 
international food markets, and through 'insulating' domestic food markets from international price fluctuations. Together those policy attributes magnify the effect on international prices of any shock to global food supply or demand.

The solution to the first ('thinning') problem is simple economically if not politically: it is for countries to open further their markets to food trade. The political difficulty and the adjustment costs associated with doing that are minimized if countries can agree to liberalize their food and agricultural markets multilaterally, and to do so at the same time as nonagricultural markets are liberalized. That was what happened in the Uruguay Round, and it is what has been aspired to by members of the World Trade Organization (WTO) via their Doha Development Agenda (DDA). After more than a decade of negotiating, the DDA has come to a standstill, but there is still hope that the talks will be revived. Meanwhile, various plurilateral negotiations on options for regional integration and free-trade areas are under discussion, but the benefits from them are always far smaller than those from a multilateral agreement and often agriculture is the sector liberalized least (Anderson 2013).

The optimal solution to the second ('insulating') problem also involves the WTO. In a many-country world, it is clear from the above analysis that the trade policy actions of individual countries can be offset by those of other countries to the point that the interventions become ineffective in achieving their stated aim of reducing domestic food price volatility. This is a classic international public good problem that could be solved by a multilateral agreement to restrain the use of variable export restrictions.

One of the original motivations for the Contracting Parties to sign the General Agreement on Tariffs and Trade (GATT, WTO's predecessor) was to bring stability and predictability to world trade. To that end the membership has adopted rules to encourage the use of trade taxes in place of quantitative restrictions on trade (Article IX of the GATT), and has managed to obtain binding commitments on import tariffs and on production and export subsidies as part of the GATT's Uruguay Round Agreement on Agriculture. However, those bindings continue to be set well above applied rates by most countries, leaving plenty of scope for varying import restrictions without dishonoring those legal commitments under WTO. Meanwhile, there are no effective disciplines on export taxes, let alone bindings.

In the current Doha round of WTO negotiations there are proposals to phase out agricultural export subsidies as well as to bring down import tariff bindings, both of which would contribute to global economic welfare, the 'thickening' of food and agricultural markets, and thereby more-stable international food prices. However, proposals to broaden the Doha agenda to also introduce disciplines on export restraints have struggled to date to 
gain traction. A proposal by Japan in 2000, for example, involved disciplines similar to those on the import side, with export restrictions to be replaced by taxes and export taxes to be bound and gradually phased down. A year later Jordan proposed even stronger rules: a ban on export restrictions and, as proposed for export subsidies, the binding of all export taxes at zero. However, strong opposition to the inclusion of this export item on the Doha Development Agenda has come from several food-exporting developing countries, led by Argentina (whose farm exports have been highly taxed since its large currency devaluation at the end of 2001). This reflects the facts that traditionally the demandeurs in WTO negotiations have been dominated by interests seeking market access, and that upward price spikes are infrequent. Yet the above analysis reveals the need for symmetry of treatment of export and import disciplines in the WTO.

Moreover, developing countries have added to the WTO's Doha Agenda a proposal for a Special Safeguards Mechanism (SSM) that would allow those countries to raise their agricultural import barriers above their bindings for a significant proportion of farm products in the event of a sudden international price fall or an import surge. This is the exact opposite of what is needed by way of an international public good to reduce the frequency and amplitude of downward food price spikes (Hertel, Martin and Leister 2010). Evidence provided by Anderson and Nelgen (2012a) for the mid-1980s suggests that if food-importing countries were to exercise that proposed freedom when international prices slump, foodsurplus countries would respond by lowering their export restrictions - thereby weakening the efforts of the food-importing countries to insulate their domestic markets from the international price fall - and further depressing that price.

If WTO member countries were to liberalize their food trade and bind their trade taxes at low or zero levels, and assuming there would still be occasions when international food prices spike, what alternative instruments could they use to avert losses for significant groups in their societies? A standard answer from economists is that food security for consumers, most notably food affordability for the poor, is best dealt with using generic social safety net measures that offset the adverse impacts of a wide range of different shocks on poor people net sellers as well as net buyers of food - without imposing the costly by-product distortions that necessarily accompany the use of $\mathrm{n}^{\text {th }}$-best trade policy instruments for social protection. That might take the form of targeted income supplements to only the most vulnerable households, and only while the price spike lasts. This standard answer has far greater power now than just a few years ago, thanks to the digital information and communication technology (ICT) revolution. In the past it has often been claimed that such payments are 
unaffordable in poor countries. However, recall that in half the cases considered above, governments reduce their trade taxes, so even that intervention is a drain on the finance ministry's budget in those cases. Moreover, the ICT revolution has made it possible for conditional cash transfers to be provided electronically as direct assistance to even remote and small households, and even to the most vulnerable members of those households (typically women and their young children - see, e.g., Fiszbein and Schady (2009), Adato and Hoddinott (2010) and Skoufias, Tiwari and Zaman (2010)).

Now is the time to move away from traditional national government trade policy reactions to food price spikes not only because, collectively, they are not very effective in stabilizing domestic prices, but also because they add to international price volatility by reducing the role that trade between nations can play in bringing stability to the world's food markets. That adverse aspect will become ever more important as climate change increases the frequency and severity of extreme weather events - and if current biofuel policy responses to it continue to strengthen the link between food and volatile fossil fuel markets, as Hertel and Beckman (2011) suggest is distinctly possible.

\section{References}

Adato, M. and J. Hoddinott (eds.) (2010), Conditional Cash Transfers in Latin America, Baltimore MD: Johns Hopkins University Press for IFPRI.

Aksoy, M.A. and B. Hoekman (eds.) (2010), Food Prices and Rural Poverty, London: Centre for Economic Policy Research for the World Bank.

Anderson, K. (1995), 'Lobbying Incentives and the Pattern of Protection in Rich and Poor Countries', Economic Development and Cultural Change 43(2): 401-23, January.

Anderson, K. (ed.) (2009), Distortions to Agricultural Incentives: A Global Perspective, 1955-2007, London: Palgrave Macmillan and Washington DC: World Bank.

Anderson, K. (ed.) (2010), The Political Economy of Agricultural Price Distortions, Cambridge and New York: Cambridge University Press.

Anderson, K. (2013), 'Trade Barriers and Subsidies: Multilateral and Regional Reform Opportunities", in Global Crises, Global Solutions ( $3^{\text {rd }}$ edition), edited by B.

Lomborg, Cambridge and New York: Cambridge University Press (forthcoming) Anderson, K., J. Cockburn and W. Martin (eds.) (2010), Agricultural Price Distortions, Inequality and Poverty, Washington DC: World Bank. 
Anderson, K., J. Cockburn and W. Martin (2011), 'Would Freeing Up World Trade Reduce Poverty and Inequality? The Vexed Role of Agricultural Distortions', The World Economy 34(4): 487-515, April.

Anderson, K., Y. Hayami and Others (1986), The Political Economy of Agricultural Protection: East Asia in International Perspective, London: Allen and Unwin.

Anderson, K. and S. Nelgen (2012a), 'Agricultural Trade Distortions During the Global Financial Crisis', Oxford Review of Economic Policy 28(1), Spring (forthcoming). doi:10.1093/oxrep/GRS001.

Anderson, K. and S. Nelgen (2012b), Updated National and Global Estimates of Distortions to Agricultural Incentives, 1955 to 2010, Database to be uploaded in March 2012 at www.worldbank.org/agdistortions.

Barrett, C.B. (2010), 'Measuring Food Insecurity', Science 327: 825-28, February12.

Bates, R.H. (1981), Markets and States in Tropical Africa: The Political Basis of Agricultural Policies, Berkeley: University of California Press.

Conforti, P. (2004), Price Transmission in Selected Agricultural Markets, Commodity and Trade Policy Research Working Paper 7, Food and Agriculture Organisation, Rome, March.

FAO et al. (2011), Price Volatility in Food and Agricultural Market: Policy Responses, Background Policy Report for the G20 Summit in Paris in November 2011, Rome: FAO in collaboration with IFAD, IFPRI, IMF, OECD, UNCTAD, WFP, World Bank and WTO, May.

Fiszbein, A. and N. Schady (with F.H.G. Ferreira, M. Grosh, N. Kelleher, P. Olinto and E. Skoufias) (2009), Conditional Cash Transfers: Reducing Present and Future Poverty, Policy Research Report, Washington DC: World Bank.

Haberler, G. (1958), Trends in International Trade: A Report by a Panel of Experts, Geneva: General Agreement on Tariffs and Trade, October.

Hertel, T. W. and J. Beckman (2011), 'Commodity Price Volatility in the Biofuel Era: An Examination of the Linkage Between Energy and Agricultural Markets', Ch. 6 (pp. 189-221) in The Intended and Unintended Effects of U.S. Agricultural and Biotechnology Policies, edited by J. Graff Zivin and J. Perloff, Chicago: University of Chicago Press for NBER.

Hertel, T., Martin, W. and Leister, A. (2010), 'Potential Implications of a Special Safeguard Mechanism in the World Trade Organization: The Case of Wheat', World Bank Economic Review 24(2): 330-59. 
Ivanic, M. and W. Martin (2008), 'Implications of Higher Global Food Prices for Poverty in Low-Income Countries', Agricultural Economics 39: 405-16.

Johnson, D.G. (1973, revised 1991), World Agriculture in Disarray, London: Fontana.

Krueger, A.O., M. Schiff and A. Valdés (1988), 'Agricultural Incentives in Developing Countries: Measuring the Effect of Sectoral and Economy-wide Policies', World Bank Economic Review 2(3): 255-72, September.

Krueger, A.O., M. Schiff and A. Valdés (1991), The Political Economy of Agricultural Pricing Policy, Volume 1: Latin America, Volume 2: Asia, and Volume 3: Africa and the Mediterranean, Baltimore MD: Johns Hopkins University Press for the World Bank.

Martin, W. and K. Anderson (2012), 'Export Restrictions and Price Insulation During Commodity Price Booms', American Journal of Agricultural Economics 94(2): 42227, January.

Minot, N. (2011), 'Transmission of World Food Price Changes to Markets in Sub-Saharan Africa', Discussion Paper 1059, IFPRI, Washington DC, February.

Nelgen, S. (2012), Distortions to Agricultural Markets: Trends and Fluctuations, 1955 to 2010, unpublished PhD thesis, University of Adelaide, Adelaide, June.

Nerlove, M. (1972), 'Lags in Economic Behaviour', Econometrica 40(2): 221-52, March.

Pinstrup-Andersen, P. (2009), 'Food Security: Definition and Measurement', Food Security 1(1): 5-7, February.

Sandri, D., E. Valenzuela and K. Anderson (2007), 'Economic and Trade Indicators, 1960 to 2004’, Agricultural Distortions Working Paper 02, World Bank, Washington DC. Posted at www.worldbank.org/agdistortions.

Skoufias, E., S. Tiwari and H. Zaman (2010), 'Can We Rely on Cash Transfers to Protect Dietary Diversity During Food Crises? Estimates from Indonesia', Policy Research Working Paper 5548, World Bank, Washington DC, January.

Tyers, R. and K. Anderson (1992), Disarray in World Food Markets: A Quantitative Assessment, Cambridge and New York: Cambridge University Press.

Wright, B.D. (2011), 'The Economics of Grain Price Volatility', Applied Economic Perspectives and Policy 33(1): 32-58, Spring.

World Bank (2012), Pink Sheets, http://econ.worldbank.org, accessed 18 March. 
Figure 1: Effects of offsetting export barrier increases and import barrier reductions in the international market for food in response to an exogenous supply shock from $\mathrm{ES}_{0}$ to $\mathrm{ES}_{1}$

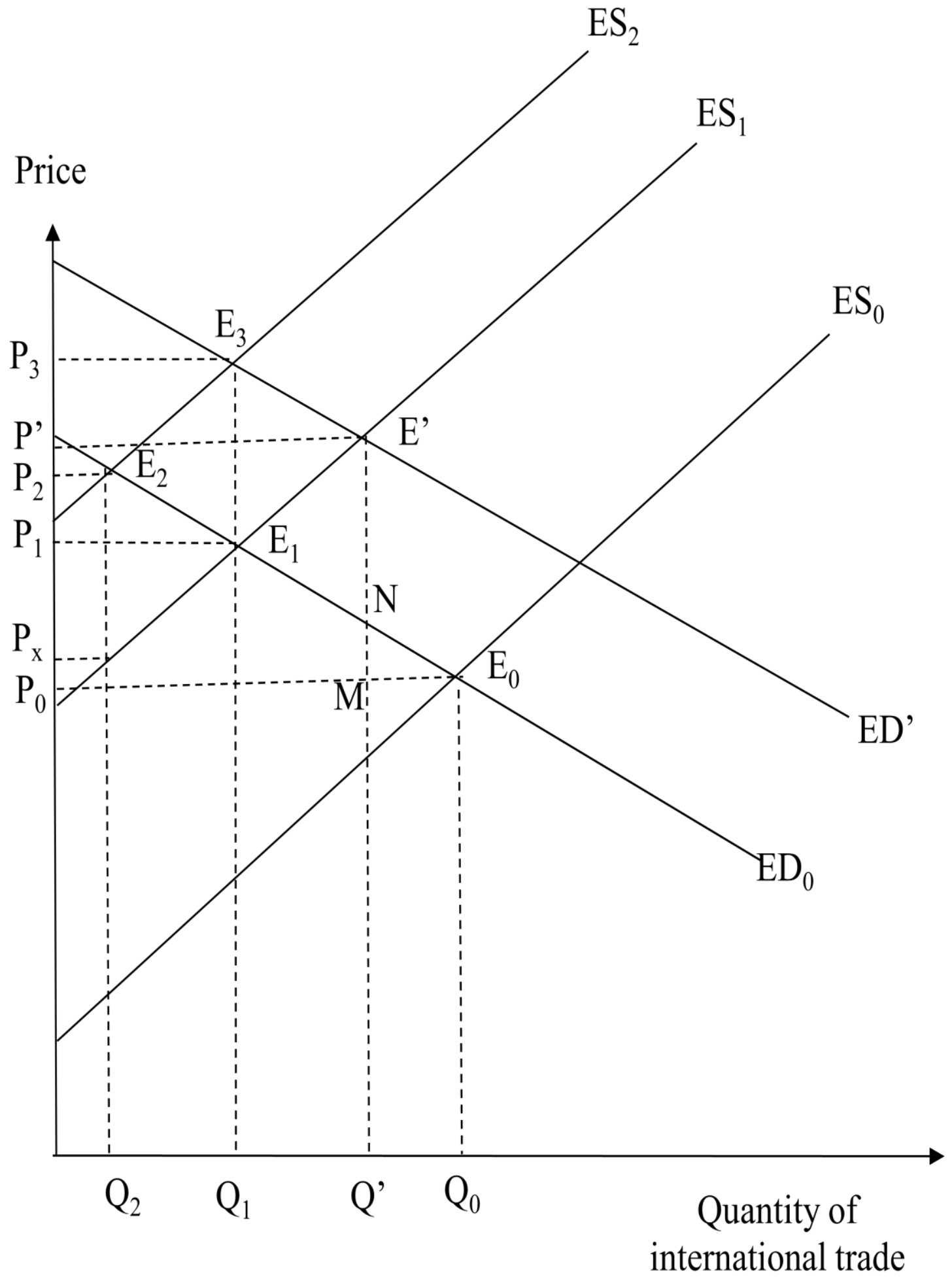

Source: Author's depiction 
Figure 2: Nominal rates of assistance to farmers (NRA) ${ }^{\mathrm{a}}$, high-income and developing countries, 1955 to 2010

(percent)

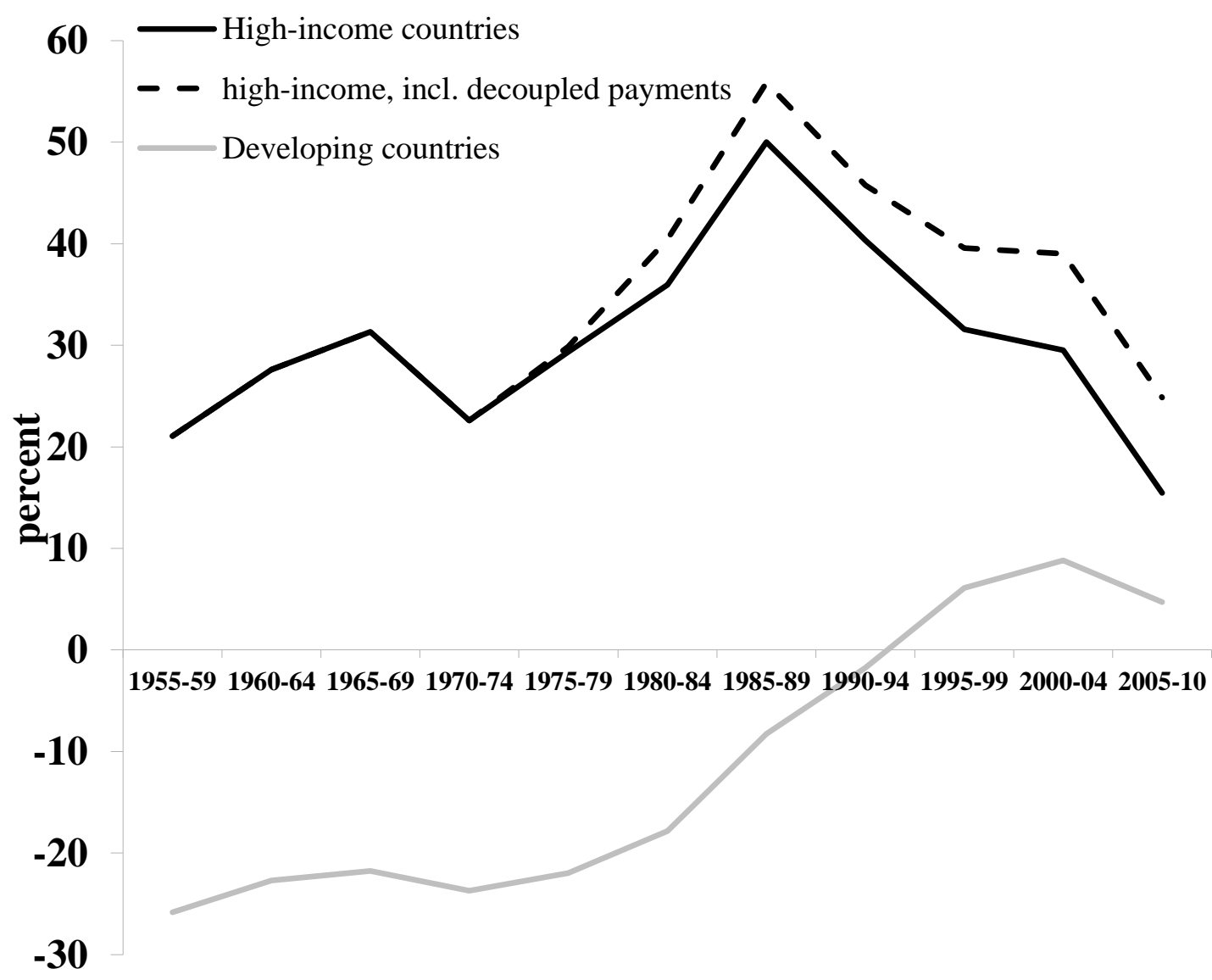

${ }^{a}$ The percentage by which gross earnings from farming in each country exceed what they would in the absence of national agricultural price and trade policies. The weighted average across products within countries, and across countries, is obtained using the value of agricultural production at undistorted prices as weights.

Source: Updated from Anderson (2009), drawing on estimates in Anderson and Nelgen (2012b). 
Figure 3: Grain NRAs and their international price, 82 countries, ${ }^{\text {a }} 1970$ to 2011

(left axis is international price in current US\$, right axis is weighted average NRA in percent)

(a) Rice

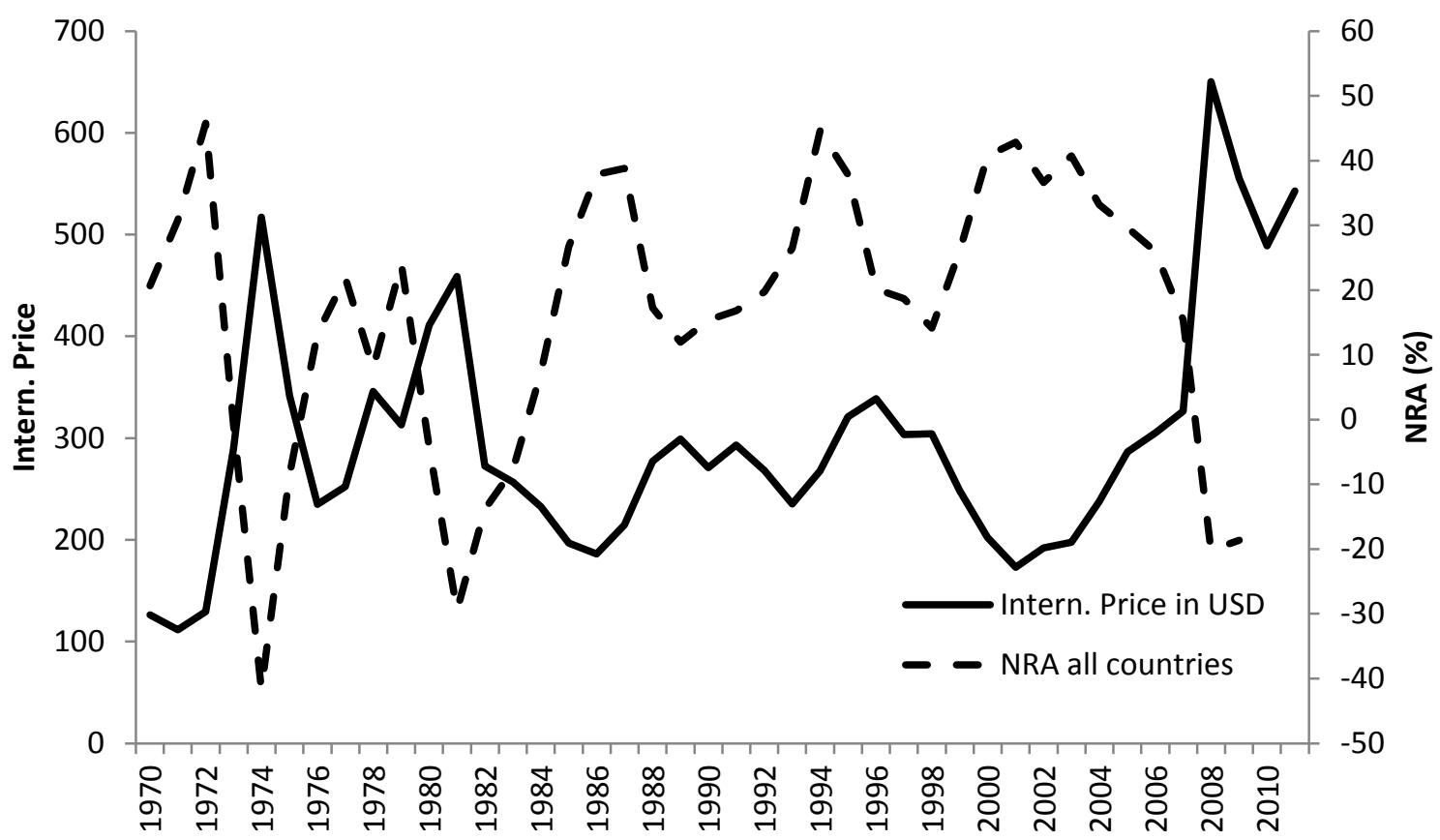

(b) Wheat

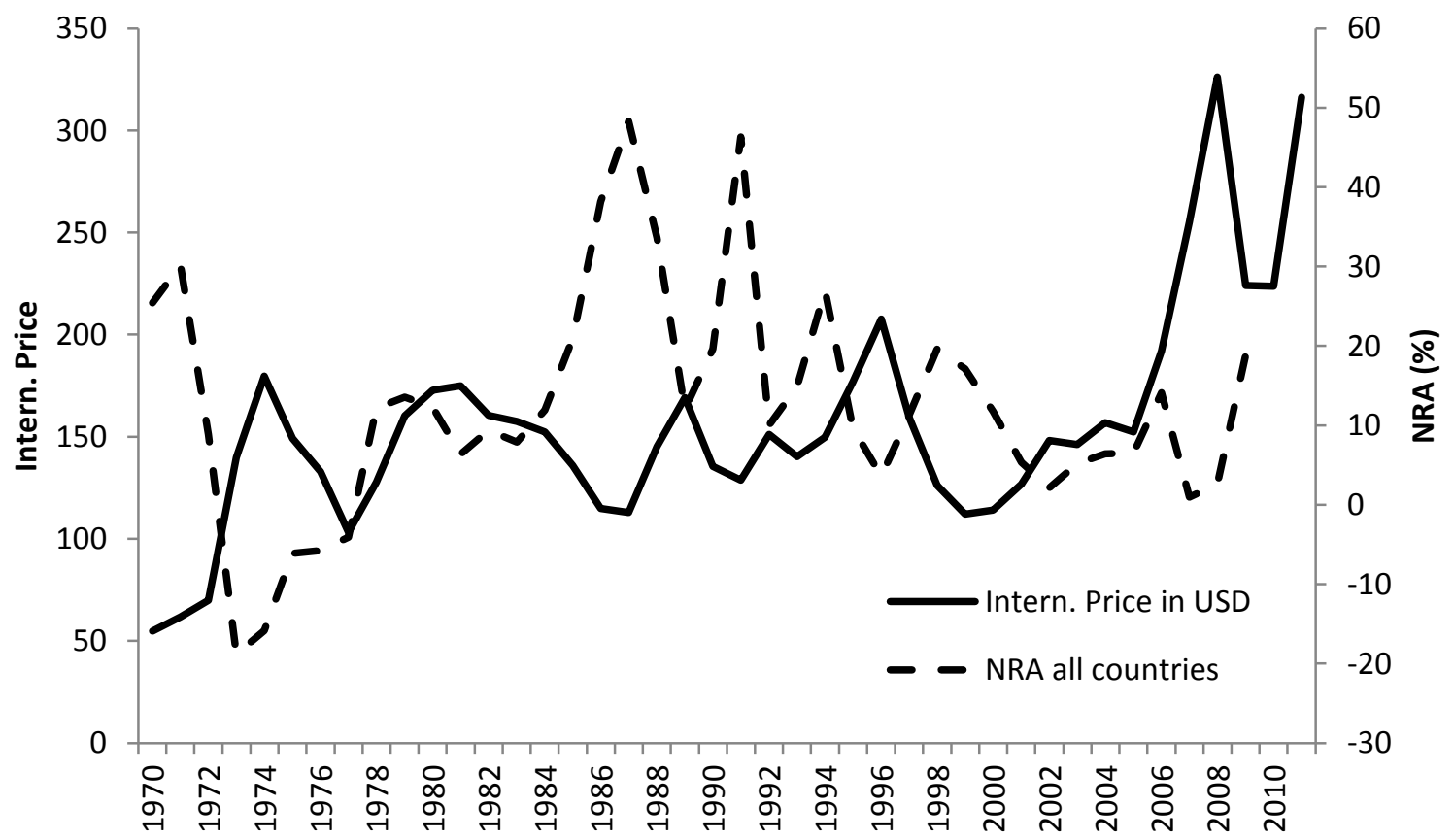


Figure 3 (continued): Grain NRAs and their international price, ${ }^{\mathrm{a}} 82$ countries, 1970 to 2011 (left axis is international price in current US\$, right axis is weighted average NRA in percent)

(c) Maize

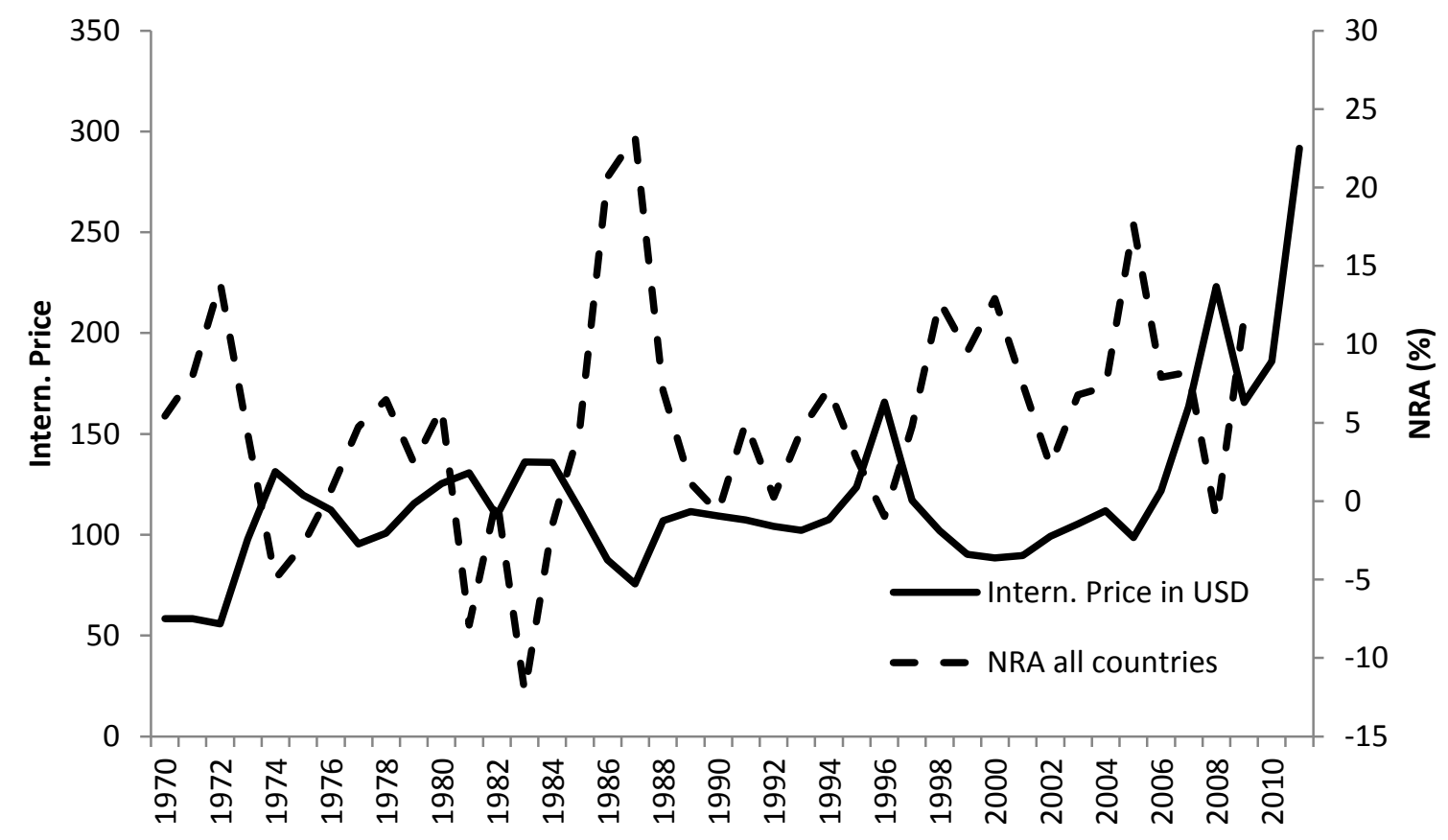

${ }^{a}$ The NRA is a weighted average of the nominal rate of assistance to producers in each country, using production valued at undistorted prices as weights. The international prices are from World Bank (2011). Coefficients of correlation between the price and NRA are -0.76 for rice, -0.32 for wheat and -0.45 for maize.

Source: Anderson and Nelgen (2012b). 
Table 1: Global average short-run price transmission elasticities, ${ }^{\mathrm{a}}$ key foods, 1985 to 2010 (weighted average across all of the 82 countries for which NRAs are available, using value of national production at undistorted prices as weights)

\begin{tabular}{lc} 
Rice & 0.49 \\
Wheat & 0.55 \\
Maize & 0.63 \\
Soybean & 0.73 \\
Sugar & 0.43 \\
Cotton & 0.57 \\
Milk & 0.51 \\
Beef & 0.66 \\
Pigmeat & 0.51 \\
Poultry & \\
Unweighted average, & 0.68 \\
10 products & \\
\hline
\end{tabular}

\footnotetext{
${ }^{a}$ The proportion of a change in the international price that is transmitted to the domestic market of a country within a year, estimated using equation (3) in the text.
}

Source: Estimated by Nelgen (2012) using equation (3) and data from Anderson and Nelgen (2012b). 
Table 2: Contributions of policy-induced trade barrier changes to changes in the international prices of key agricultural products, 1972-74 and 2006-08

$\underline{1972-74}$

2006-08

Consumption-weighted proportional decline in NAC, that is, $-\widehat{T}^{a}$

Rice

0.56

0.37

Wheat

0.30

0.12

Maize

0.21

0.08

Proportional international price rise, $\hat{\mathrm{p}}^{*}$

Rice

Wheat

1.57

0.70

Maize

1.35

0.83

Proportional contribution of changed trade restrictions to the international price change $^{\mathrm{b}}$

$\begin{array}{lll}\text { Rice } & 0.27 & 0.40 \\ \text { Wheat } & 0.23 & 0.19 \\ \text { Maize } & 0.18 & 0.10\end{array}$

${ }^{a} \widehat{T}$ is the negative of the weighted average of proportional changes in national NACs over the period, using national shares of global consumption valued at undistorted prices $\left(\mathrm{G}_{\mathrm{i}}{ }^{\prime} \mathrm{s}\right)$ as weights, where $\mathrm{NAC}=1+\mathrm{NRA} / 100$.

b The proportional contribution of altered trade restrictions is $\frac{\widehat{T}}{\widehat{T}+R}$, where $\mathrm{R}$ is 'other' influences and is derived from the equation $\hat{\mathrm{p}}^{*}=\widehat{T}+R+(\widehat{T} * R)$, from which it follows that $\mathrm{R}=\left(\hat{\mathrm{p}}^{*}-\widehat{T}\right) /(1+\widehat{T})$.

Source: Anderson and Nelgen (2012a). 
Table 3: Contributions ${ }^{\mathrm{a}}$ of high-income and developing countries, and of importing and exporting countries, to the proportion of the international price change that is due to policyinduced trade barrier changes, 1972-74 and 2006-08

\begin{tabular}{|c|c|c|c|c|c|}
\hline & $\begin{array}{c}\text { TOTAL } \\
\text { PROPORTIONAL } \\
\text { CONTRIBUTION }\end{array}$ & $\begin{array}{l}\text { High-income } \\
\text { countries' } \\
\text { contribution }\end{array}$ & $\begin{array}{l}\text { Developing } \\
\text { countries' } \\
\text { contribution }\end{array}$ & $\begin{array}{l}\text { Importing } \\
\text { countries' } \\
\text { contribution }\end{array}$ & $\begin{array}{l}\text { Exporting } \\
\text { countries' } \\
\text { contribution }\end{array}$ \\
\hline \multicolumn{6}{|c|}{$1972-74$} \\
\hline Rice & 0.27 & 0.04 & 0.23 & 0.10 & 0.17 \\
\hline Wheat & 0.23 & 0.15 & 0.08 & 0.18 & 0.05 \\
\hline Maize & 0.18 & 0.14 & 0.04 & 0.06 & 0.12 \\
\hline \multicolumn{6}{|c|}{ 2006-08 } \\
\hline Rice & 0.40 & 0.02 & 0.38 & 0.18 & 0.22 \\
\hline Wheat & 0.19 & 0.09 & 0.10 & 0.07 & 0.12 \\
\hline Maize & 0.10 & 0.05 & 0.05 & 0.03 & 0.07 \\
\hline
\end{tabular}

${ }^{\text {a }}$ Expressed such that the two numbers in each subsequent pair of columns add to the total proportion shown in column 1 of each row.

Source: Anderson and Nelgen (2012a), with the left column coming from bottom one-third of Table 2. 
Table 4: Comparison of the domestic price rise with the rise in international grain prices net of the contribution of changed trade restrictions, rice, wheat and maize, 1972-74 and 2006-08

(percent, unweighted averages)

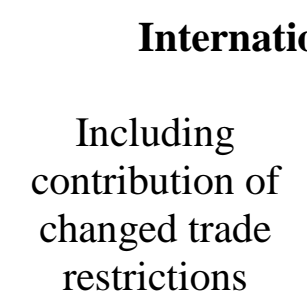

price rise

Net of
contribution of
changed trade
restrictions

$\underline{1972-74}$

Rice

300

157

135

Maize

2006-08

Rice

113

Wheat

70

Maize

83
220

121

111

68

56

75

\section{Domestic price rise}

All

countries

Developing

High-

countries income countries

59

72

27

64

77

55

49

48

52

56

48

74

77

65

81

73

62

82

Source: Anderson and Nelgen (2012a) 